Azotemia

growth retardation

growth transplantation renal transplantation somatomedin

\title{
Somatomedin and Growth after Renal Transplantation
}

\author{
Paul Saenger, ${ }^{[47]}$ Eckehart Wiedemann, Ernest Schwartz, Sigrun Korth-Schutz, John E. Lewy, \\ Robert R. Riggio, Albert L. Rubin, Kurt H. Stenzel, and Maria I. New \\ Department of Pediatrics, Divisions of Pediatric Endocrinology and Nephrology, and the Rogosin Kidney Disease Treatment Center, \\ The New York Hospital-Cornell Medical Center, New York, and the Metabolic Unit, Department of Medicine, \\ Veterans Administration Hospital, Bronx, New York, USA
}

\section{Extract}

Hormonal and metabolic factors which influence growth were studied in nine growthretarded uremic children who received renal homografts. Post-transplant growth velocity based on bone age (GVBA) became normal in four (88-103\%), accelerated in two $(127-139 \%)$, and remained subnormal in three $(18-50 \%)$. Serum somatomedin $(\mathrm{SM})$, was very low in all children before transplant $(0.39 \pm 0.10 \mathrm{U} / \mathrm{ml})$, but rose in each child after transplantation. Post-transplant somatomedin $(0.84 \pm$ $0.14 \mathrm{U} / \mathrm{ml}$ ) was not significantly different from the somatomedin of eight healthy male control subjects matched for bone age $(1.03 \pm 0.16)$. Post-transplant GVBA was directly correlated $(P<0.05)$ with serum somatomedin and creatinine clearance $\left(\mathrm{C}_{\mathrm{cr}}\right)$, but was not related to stimulated growth hormone response or to other variables of endocrine function. The data suggested that the growth failure in our patients with severe chronic uremia was due, at least in part, to lack of serum somatomedin. However, in four of five patients with persisting moderate azotemia $\left(\mathrm{C}_{\mathrm{cr}}\right.$ $\left.11.8-42.5 \mathrm{ml} / \mathrm{min} / 1.73 \mathrm{~m}^{2}\right)$, subnormal growth continued despite relatively normalized serum somatomedin activity. Three of the four poorly growing azotemic patients had the highest average steroid dosages in the group (prednisolone $>9.1$ $\mathrm{mg} / \mathrm{m}^{2} / 24 \mathrm{hr}$ ).

\section{Speculation}

If low serum somatomedin activity develops in the course of end stage renal disease in children, growth retardation may be the consequence. After renal transplantation normalization of serum somatomedin activity may be a necessary although not sufficient condition for the resumption of growth.

\section{Introduction}

Growth retardation is characteristic of children with chronic renal insufficiency. The control of renal insufficiency by homotransplantation $[3,10,12,19,22,24,28$, $41]$ has resulted in variable improvement of growth velocity. Many children resume growth at a rate less than that expected for their chronologic age [24], and "catch-up growth" has been observed only rarely $[10$, 24]. Impaired growth associated with uremia has been speculatively attributed to many causes including uremic toxicity, anemia, undernutrition, acidosis, and diminished renal concentrating ability. The factors which influence growth response to transplantation have not been clearly defined. In a recent report [24], resumption of growth after transplantation was apparently not correlated with renal function, maintenance steroid dosage, pretransplant height, donor source of kidney, or histocompatibility typing. 
Table I. Clinical and laboratory data

\begin{tabular}{|c|c|c|c|c|c|c|c|c|c|c|c|c|c|}
\hline \multirow{2}{*}{ Patient } & \multirow{2}{*}{ Underlying disease } & \multirow{2}{*}{$\begin{array}{l}\text { Kidney } \\
\text { donor }\end{array}$} & \multirow{2}{*}{$\begin{array}{c}\text { Time } \\
\text { since } \\
\text { trans- } \\
\text { planta- } \\
\text { tion, } \\
\text { mo }\end{array}$} & \multirow{2}{*}{$\begin{array}{c}\text { Predni- } \\
\text { solone, } \\
\mathrm{mg} / \\
\mathrm{m}^{2} / 24 \\
\mathrm{hr}\end{array}$} & \multirow{2}{*}{$\mid \begin{array}{c}\text { Creati- } \\
\text { nine } \\
\text { clear- } \\
\text { ance, } \\
\mathrm{ml} / \\
\mathrm{min} / \\
1.73 \mathrm{~m}^{2}\end{array}$} & \multirow{2}{*}{$\begin{array}{c}\text { Bone age } / \\
\text { chronologic } \\
\text { age, yr }\end{array}$} & \multirow[b]{2}{*}{ 20 } & \multirow{2}{*}{$\left|\begin{array}{c}\text { Sexual } \\
\text { de- } \\
\text { velop- } \\
\text { ment } \\
(\text { Tan- } \\
\text { ner } \\
\left.\text { stage }^{2}\right)\end{array}\right|$} & \multirow{2}{*}{$\begin{array}{l}\text { Glucose } \\
\text { tolerance, } \\
\mathrm{mg} / 100 \mathrm{ml}\end{array}$} & \multirow{2}{*}{$\begin{array}{c}\text { Basal } \\
\text { growth } \\
\text { hormone, } \\
\mathrm{ng} / \mathrm{ml}\end{array}$} & \multirow{2}{*}{$\begin{array}{l}\text { AITT33 }^{3} \\
\text { growth } \\
\text { hormone } \\
\text { peak, } \\
\text { ng/ml }\end{array}$} & \multicolumn{2}{|c|}{$\begin{array}{l}\text { Serum } \\
\text { somatomedin, } \\
\mathrm{U} / \mathrm{ml}\end{array}$} \\
\hline & & & & & & & & & & & & $\begin{array}{c}\text { Before } \\
\text { trans } \\
\text { plant }\end{array}$ & $\begin{array}{l}\text { After } \\
\text { trans- } \\
\text { plant }\end{array}$ \\
\hline $\begin{array}{l}\text { Supernormal GVBA } \\
D G^{4}\end{array}$ & & & & & & & & & & & & & \\
\hline $\begin{array}{c}D G^{4} \\
\text { Normal GVBA }\end{array}$ & Medullary cystic disease & Mother & 12 & 4.6 & 73.6 & $6 / 8.3$ & 139 & I & & & & 0.57 & 1.10 \\
\hline PF & Polycystic kidney disease & Father & 28 & 4.5 & 93.5 & $7 / 13$ & 103 & I & Normal & $<1.0$ & 16.0 & 0.57 & 0.94 \\
\hline$H T$ & Medullary cystic disease & Cadaver & 12 & 6.3 & 40.3 & $12.5 / 17.5$ & 103 & III & Normal & 4.7 & 23.0 & 0.39 & 0.88 \\
\hline$J C$ & $\begin{array}{l}\text { Chronic pyelonephritis, sec- } \\
\text { ondary to left renal agene- } \\
\text { sis and right ureteropelvic } \\
\text { obstruction }\end{array}$ & Mother & 9 & 1.7 & 94.0 & $3 / 8.8$ & 89 & I & Not done & $<\mathrm{I}$ & 24.0 & 0.35 & 0.71 \\
\hline$T W$ & $\begin{array}{l}\text { Chronic pyelonephritis, sec- } \\
\text { ondary to urethral valves } \\
\text { and right hypoplastic kid- } \\
\text { ney }\end{array}$ & Mother & 42 & 3.7 & 86.5 & $15.5 / 17.5$ & 88 & III & Normal & 2.5 & 9.6 & 0.47 & 0.81 \\
\hline Subnormal GVBA & & & & & & & & & & & & & \\
\hline$S C$ & $\begin{array}{l}\text { Nephrotic syndrome with } \\
\text { focal and segmental sclero- } \\
\text { sis }\end{array}$ & Mother & 9 & 20.0 & 42.2 & $6.5 / 9.5$ & 50 & I & Not done & & & 0.37 & 0.72 \\
\hline$D G^{5}$ & (Second study) & & 60 & 4.0 & 29.6 & $11.5 / 12.7$ & 42 & II & Normal & 1.6 & 14.0 & & 0.91 \\
\hline$P C$ & Medullary cystic disease & Cadaver & 22 & 9.1 & 11.8 & $9 / 15$ & 22 & II & Not done & 1.8 & 7.7 & 0.38 & 0.81 \\
\hline$R M$ & $\begin{array}{l}\text { Chronic proliferative glo- } \\
\text { merulonephritis }\end{array}$ & Father & 12 & 12.5 & 19.7 & $11 / 14.5$ & 18 & II & Abnormal & 13.0 & 73.0 & 0.28 & 0.58 \\
\hline
\end{tabular}

1 GVBA : growth velocity in percentage of expected growth velocity for bone age.

2 Tanner stages: stage I, prepubertal; stages $I I-V$, progressive stages of pubertal development.

3 AITT: arginine-insulin tolerance test.

- During period of catch-up growth.

6 During period of reduced growth and chronic renal rejection.

The present investigation has attempted to identify, in nine children, the influence of various endocrine and metabolic factors upon growth velocity after transplantation. Inasmuch as growth hormone-dependent somatomedin (sulfation factor) is believed to be a principal determinant of linear growth $[5,6,14,30]$, preand post-transplant serum somatomedin levels in our patients were of special interest.

\section{Materials and Methods}

\section{Patients}

Nine male children, ranging in age from 7-16 years, received 10 transplants (Table I). At the time of the study, the patients had survived between 9 months and 5 years after transplantation. All patients were receiving prednisolone and azathioprine maintenance therapy. One patient, $D G$, was studied twice because of a major decrease in growth and renal function which occurred some time after transplantation.

\section{Clinical and Laboratory Procedures}

All patients were admitted as necessary to The New York Hospital-Cornell Medical Center Clinical Research Center. Serial heights, measured with the Har- penden stadiometer, were plotted using tables of the State University of Iowa growth standards. Bone age was estimated according to the method of Greulich and Pyle [13]. Pubertal status was evaluated and staged according to the method of Tanner [36]. Post-transplant growth performance was analyzed for the 12-month period ending at the time of evaluation and was related to bone age rather than chronologic age, because bone age appears to be more fundamentally related to growth velocity and was severely retarded in the patients. Growth velocity for bone age was calculated as follows:

GVBA $(\%)=\frac{\text { observed height gain }(\mathrm{cm} / \text { year })}{\text { expected height gain for bone age }} \times 100$.

Expected height gain for bone age was obtained from the data of Tanner et al. [37] which substitutes the observed bone age for chronologic age in Tanner's tables. The normal range for GVBA was assumed to be the mean $\pm 2 \mathrm{sD}$. In the nine patients studied, growth velocity, renal function and immunosuppressive therapy did not vary significantly during the 12-month reference periods. Creatinine clearance, expressed as milliliters per minute per $1.73 \mathrm{~m}^{2}$, was calculated from the mean value of two serial 24-hr values for creatinine 
in urine and one fasting serum creatinine. Creatinine was determined by the standard picric acid method [17]. If the two values of 24-hr creatinine in urine were widely discrepant, the urine collections were repeated.

Stimulation tests of plasma growth hormone response were performed in seven patients, using a sequential intravenous arginine-insulin protocol [27]: $5 \%$ arginine hydorchloride in a dose of $0.5 \mathrm{~g} / \mathrm{kg}$ was infused over 30 min; after $1 \mathrm{hr}$, this was followed by an intravenous injection of regular insulin, $0.1 \mathrm{U} / \mathrm{kg}$. Adequate hypoglycemia was defined as a $50 \%$ decrease of sugar level in blood [27]. Plasma growth hormone was determined by radioimmunoassay [11]. Growth hormone response was considered normal if a plasma level of at least 5 $\mathrm{ng} / \mathrm{ml}$ was observed at any time.

Plasma growth hormone levels were also determined during the glucose tolerance tests.

Serum somatomedin activity was determined by bioassay [39]. The index of precision for this bioassay ranged from $0.09-0.52$ (mean 0.25 ). The in vitro uptake of ${ }^{35}$ S-sulfate uptake by hypophysectomized rat costal cartilage was calculated as units per milliliter, where 1 $\mathrm{U}$ was equivalent to the activity of $1 \mathrm{ml}$ of our laboratory reference serum obtained from 10 healthy adult males. Because the rib uptake of ${ }^{35} \mathrm{~S}$-sulfate is dependent upon isotope dilution in the total inorganic sulfate pool of the incubation mixture [8], the abnormally high levels of inorganic sulfate in uremic sera (up to 10 times normal) artifactually reduced observed rib ${ }^{35} \mathrm{~S}$-sulfate uptake by as much as $30 \%$. Therefore, the serum inorganic sulfate concentration as measured by the benzidine method [18] was taken into account in calculations of ${ }^{35} \mathrm{~S}$-sulfate uptake during assays of uremic sera. Sera to be assayed for somatomedin activity were stored at $-15^{\circ}$ until the time of assay. All of the posttransplant sera were stored for less than 1 year before assay except one post-transplant serum from $D G$ (study $1)$, which was 4.5 years old. The pre-transplant sera were stored for 3 months -5.5 years before assay. Specimens from $D G($ study 1$)$ and $T W$ were stored for 5.5 years and 4 years, respectively, while none of the other pretransplant sera were stored longer than 2.5 years. Although the question of stability of serum somatomedin has not yet been studied specifically, we have seen no definitive decrease of activity of sera stored in the frozen state for up to 2 years. All samples were assayed simultaneously.

Oral glucose tolerance tests were performed in six patients, using a glucose dose of $1.75 \mathrm{~g} / \mathrm{kg}$ with a maximum of $100 \mathrm{~g}$. Glucose intolerance was defined by the criteria of the American Diabetes Association. Thyroid function was evaluated by serum protein-bound iodine and ${ }^{131} \mathrm{I}$ thyroidal uptake. Adrenal androgen secretion was evaluated by the determination of 24-hr excretion of 17-ketosteroids in urine [26]. Plasma follicle-stimulating hormone and luteinizing hormone were determined by radioimmunoassay [32]. The average daily caloric intake was estimated by a dietician and expressed as percentage of recommended caloric intake, based upon the 1968 Recommended Dietary Allowances (RDA) for children of the same height [25]. After transplantation, all patients were on an unrestricted diet, and caloric intakes met or exceeded the recommended dietary allowances.

\section{Results}

Detailed clinical and laboratory data are presented in Table I.

\section{Renal Function after Transplantation}

After transplantation, four patients $(G L, P F, J C$, and $T W$ ) had relatively normal renal function until the time of study, with creatinine clearances $\left(\mathrm{C}_{\mathrm{cr}}\right)$ which ranged from $40.3-93.5 \mathrm{ml} / \mathrm{min} / 1.73 \mathrm{~m}^{2}$. These patients received prednisolone dosages of $1.7-4.5 \mathrm{mg} / \mathrm{m}^{2} / 24 \mathrm{hr}$. Four patients $(H T, P C, S C$, and $R M)$ were in a state of chronic rejection of the renal homograft at the time of study and throughout the 12 -month period preceding it. These patients had $\mathrm{C}_{\mathrm{cr}}$ from $11.8-42.2 \mathrm{ml} / \mathrm{min} / 1.73$ $\mathrm{m}^{2}$, and received $4.0-20.0 \mathrm{mg}$ prednisolone $/ \mathrm{m}^{2} / 24 \mathrm{hr}$. Patient $D G$ had a biphasic response. For the first 2 years after transplant (phase $I$ ), $\mathrm{C}_{\mathrm{cr}}$ was over $70 \mathrm{ml} / \mathrm{min} /$ $1.73 \mathrm{~m}^{2}$. Thereafter, he entered his present phase of poor renal function (phase $I I$ ) with $\mathrm{C}_{\mathrm{cr}}$ of less than 30 $\mathrm{ml} / \mathrm{min} / 1.73 \mathrm{~m}^{2}$.

\section{Growth Performance after Transplant}

As shown in Figures 1 and 2, growth was markedly retarded in all children at the time of transplantation and all, except $R M$, were at or below the 3rd percentile for height. After transplantation, absolute growth rate (centimeters per year) remained essentially unchanged in four patients ( $T W, S C, P C$, and $R M$ ) (Fig. 2); increased in four (GL, $P F, H T$, and $J C$ ) (Fig. 1), and showed a biphasic response in $D G$ (Fig. 1).

The GVBA after transplantation (Table I) was normal (88-103\%) in four patients $(P F, H T, J C$, and $T W)$; above normal (127\%) in one (GL); subnormal in three $(S C, P C$, and $R M)$, and biphasic in $D G$ in whom it was 


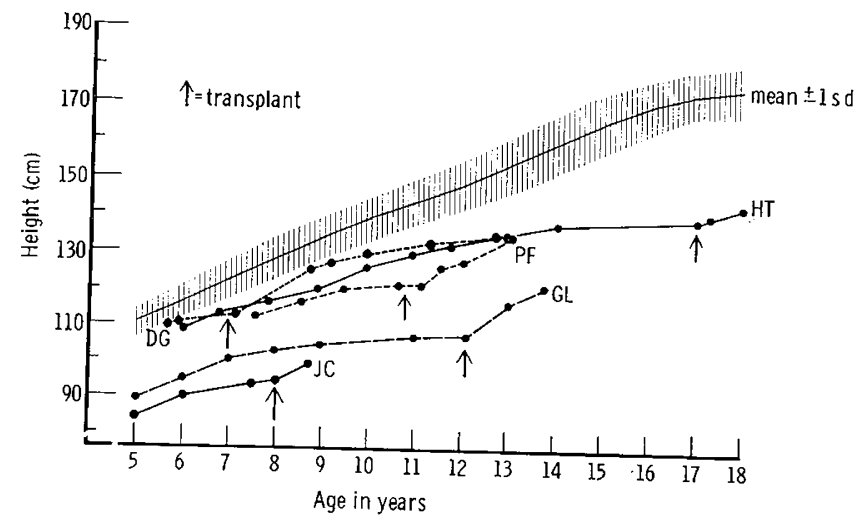

Fig. 1. Growth curves of paticnts with unimpaired growth rate after renal transplantation.

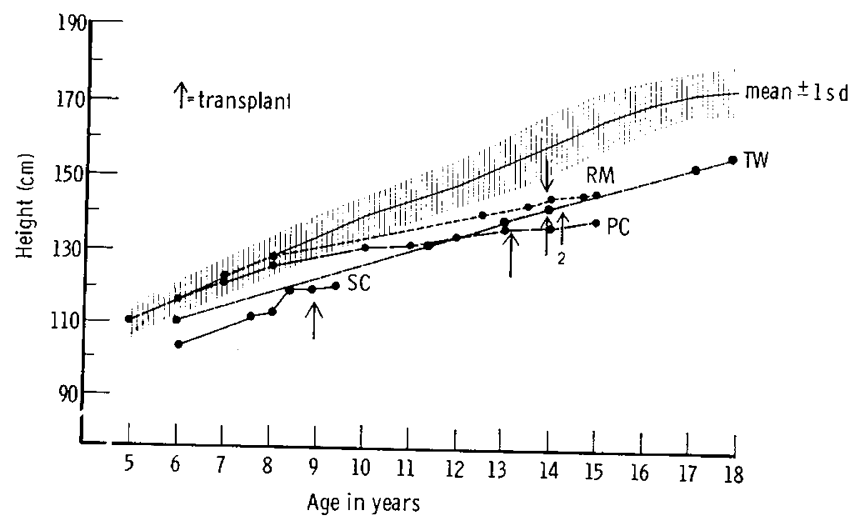

Fig. 2. Growth curves of patients with decreased growth rate after renal transplantation. Patient $D G$ had initially accelerated growth after transplantation which slowed markedly as renal function decreased.

above normal (139\%) during phase $I$ and subnormal (42\%) during phase II.

\section{Endocrine Function}

Thyroid ${ }^{131}$ I uptake, protein-bound iodine, 17-ketosteroids in urine, and plasma follicle-stimulating hormone and luteinizing hormone were all within normal limits in all patients. Sexual development after transplant corresponded reasonably with observed bone age. Oral glucose tolerance was abnormal in two of the six patients studied, one of whom $(R M)$ was azotemic and receiving high doses of prednisolone $\left(12.5 \mathrm{mg} / \mathrm{m}^{2} / 24\right.$ hr) at the time, while the other $(G L)$ had normal renal function $\left(\mathrm{C}_{\mathrm{cr}} 67.6 \mathrm{ml} / \mathrm{min} / 1.73 \mathrm{~m}^{2}\right)$ and was on low dose prednisolone $\left(2.8 \mathrm{mg} / \mathrm{m}^{2} / 24 \mathrm{hr}\right)$.

Basal growth hormone levels were normal ( $<5 \mathrm{ng}$ / $\mathrm{ml}$ ) in all patients except $R M$, in whom it was $13 \mathrm{ng} /$ $\mathrm{ml}$. Peak growth hormone levels after arginine-insulin tolerance test were normal in patients tested except $R M$, in whom it was greatly elevated $(73 \mathrm{ng} / \mathrm{ml})$. During glucose tolerance testing no patient had a paradoxical elevation of plasma growth hormone, and most patients had suppression below basal growth hormone levels.

\section{Somatomedin}

Mean pretransplant serum somatomedin activity in units per milliliter $( \pm 1 \mathrm{SD})$ in the nine uremic children was $0.39( \pm 0.10)$ as compared with $1.03( \pm 0.16)$ in eight healthy male children matched for bone age (Fig. 3). After transplantation, somatomedin activity rose by at least $65 \%$ in each child. The mean post-transplant somatomedin activity was $0.84 \pm 0.15$, not significantly different from the healthy control subjects. Post-transplant SM was not significantly correlated with $\mathrm{C}_{\mathrm{cr}}(\mathrm{r}=+0.327 ; P>0.1)$, which indicates that mild to moderate renal functional impairment has no substantial effect upon serum somatomedin.

\section{Correlation between GVBA and Other Variables (Table II)}

A significant positive correlation was demonstrable between GVBA and serum somatomedin activity $(\mathrm{r}=$

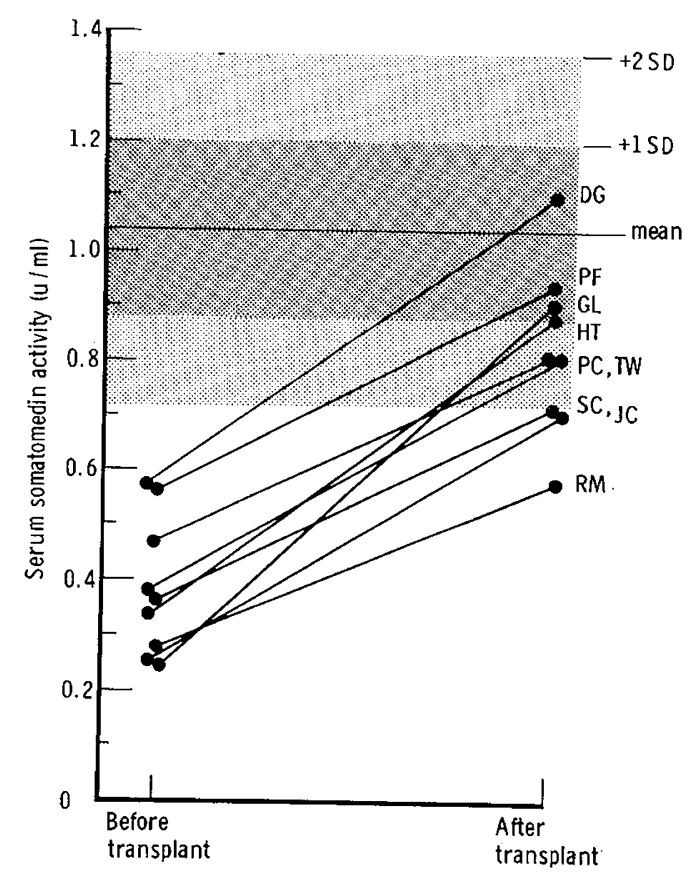

Fig. 3. Increase of serum somatomedin activity after renal trans. plantation. Heavily and lightly shaded areas represent 1 and 2 sD limits of serum somatomedin activity in normal children. 
Table II. Correlation coefficients ${ }^{1}$

\begin{tabular}{lccc}
\hline & $\begin{array}{c}\text { Prednisolone } \\
\text { dose }\end{array}$ & $\begin{array}{c}\text { Creatinine } \\
\text { clearance }\end{array}$ & SM \\
\hline GVBA & -0.571 & $+0.749^{2}$ & $+0.702^{2}$ \\
SM & -0.502 & +0.327 & \\
$\begin{array}{c}\text { Creatinine } \\
\quad \text { clearance }\end{array}$ & -0.559 & & \\
\hline
\end{tabular}

${ }^{1} \mathrm{SM}$ : serum somatomedin; GVBA: growth velocity for bone age.

$2 P<0.05$.

$+0.702 ; P<0.05$ ) (Fig. $4 a$ ). The GVBA was also significantly positively correlated with $\mathrm{C}_{\mathrm{cr}}(\mathrm{r}=+0.749$; $P<0.05$ ) (Fig. $4 b$ ). On the other hand, there was only a slight negative correlation $(r=-0.571)$ between GVBA and prednisolone dose (Fig. 4c). The borderline significance of this correlation $(0.05<P<0.1)$ was entirely dependent upon the inclusion of the three patients receiving the highest prednisolone dosages, two of whom also had the poorest renal function.

\section{Discussion}

The effect of restoration of renal function upon growth should be considered in terms of a postulated growth hormone-somatomedin-end organ system. It is now well established that growth hormone does not act directly on skeletal tissues, i.e., cartilage and bone, but rather via generation of somatomedin, a hormonal polypeptide in serum formerly called "sulfation factor" $[5,6,14]$. Subnormal levels of serum somatomedin and associated growth retardation are characteristics of the hypopituitary hyposomatotrophic state $[1,9]$. Elevated levels of somatomedin and excessive skeletal growth are characteristics of acromegaly, a hypersomatrophic state $[1,9]$. Furthermore, growth response and serum somatomedin response have been shown to be closely cor- related in growth hormone-treated hypopituitary children [16]. In our group of transplanted subjects, basal and peak stimulated growth hormone levels appeared essentially normal and were not correlated with growth velocities. In the five subjects ( $H T, S L, D G$ (study 2), $P C$, and $R M)$ with impaired renal function after transplantation, one patient $(R M)$ had an abnormally elevated stimulated $\mathrm{GH}$ and an elevated basal growth hormone level, as previously described [42]. No patient had a paradoxical growth hormone response to glucose ingestion [31]. Assuming that our subjects had at least normal basal and stimulated growth hormone in the pre-transplant state of severe growth retardation, it seems probable that neither pre-transplant growth retardation nor the variable growth response to transplantation could be related to variations in growth hormone secretion.

On the other hand, the presence of low serum somatomedin levels in the pretransplant growth-retarded state and the close correlation of somatomedin levels with post-transplant growth velocity indicate a more direct relation of somatomedin to growth. Hall and Olin [16] found in growth hormone-treated hypopituitary dwarfs that both growth velocity and serum somatomedin activity rise. Although this does not necessarily mean that the rise in somatomedin activity is causative for the increase in growth velocity, the possibility cannot be excluded. Because somatomedin is at present quantified only by bioassay in vitro, interference by uremic toxins with the somatomedin bioassay must be considered. Results of preliminary ultrafiltration studies in our laboratory throw doubt upon this possibility [40]. If there is no ultrafiltrable inhibitor of the bioassay system, the level of somatomedin bioactivity in azotemic serum would then be the resultant of active physiologic processes of generation and removal in the
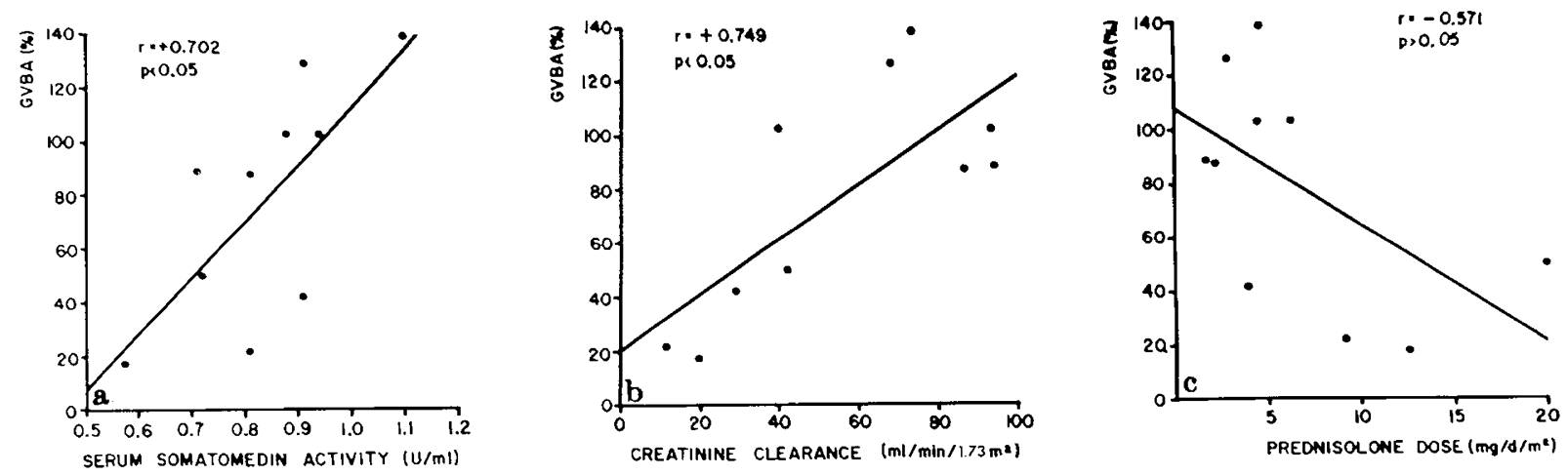

Fig. 4. Regression lines relating growth velocity for bone age to serum somatomedin (positive correlation), creatinine clearance (positive correlation), and prednisolone dose (negative correlation). 
azotemic subject. Nothing is known as yet about the degradative fate of serum somatomedin. There is evidence for substantial somatomedin generation by the liver [21], and also fragmentary data which suggests the presence of somatomedin in muscle [15] and perhaps even kidney [20]. The latter site would be of special relevance in uremia. In any case, it is as yet impossible to estimate the relative roles of synthesis and degradation in the regulation of serum somatomedin activity.

Some invetsigators have attributed growth failure in chronic uremia to decreased caloric intake [33, 38]. Caloric intake of $70 \%$ or more of RDA [25] was considered to be compatible with resumption of growth [33]. Although the dietary intakes of our patients were not clearly defined before transplantation, after transplantation all patients in this series were on an unlimited diet providing at least $100 \%$ of RDA of caloric intake. The difference between growing and nongrowing children after transplantation therefore could not be explained by diet.

Regardless of the mechanisms whereby uremia can affect the metabolism of somatomedin, the data indicated that relative normalization of serum somatomedin occurred after renal transplantation, even when mild azotemia persisted (patients $S C, P C$, and $D G$, phase $I I$ ). However, if azotemia persisted, the growth response remained poor in spite of normalized somatomedin levels, which suggested peripheral antagonism of somatomedin action. This peripheral resistance to somatomedin may be partially related to steroid therapy, since three of the four patients with subnormal growth velocity $(S C, P C$, and $R M$ ) had the highest average steroid dosage levels $\left(20.0,9.1\right.$, and $12.5 \mathrm{mg} / \mathrm{m}^{2} / 24 \mathrm{hr}$, respectively). Growth retardation associated with high dosage steroid therapy has been well documented [2, $23,29,34$ ] and steroidal inhibitory effects upon rat rib cartilage have been demonstrated.The in vivo uptake of radioactive sulfate by rat cartilage was inhibited when the animal was treated with large doses of hydrocortisone $[4,35]$. Likewise, the conversion by rat rib cartilage of $\left({ }^{14} \mathrm{C}\right)$ proline to hydroxyproline was inhibited by cortisol in vitro at a level of $0.9 \mu \mathrm{g} / \mathrm{ml}$ [7], a level which markedly exceeds physiologic concentrations. It is therefore possible that steroid therapy, particularly in high dosage, can contribute to apparent peripheral resistance to somatomedin action, as observed in some of our azotemic patients. The mechanisms of such peripheral antagonism are presently as obscure as the mechanisms of somatomedin stimulation of cartilaginous proliferation and linear growth.

\section{Summary}

Serum somatomedin activity was markedly deficient in a group of children with end stage renal disease and growth retardation. Somatomedin rose toward normal after renal transplantation. Continued azotemia and/or high dosage steroid therapy apparently inhibit partially resumption of growth even when somatomedin activity was normalized. An estimate of the overall frequency of low somatomedin in the uremic syndrome will require additional data from uremic children without growth retardation and from uremic adults.

\section{References and Notes}

1. Almevist, S., Ikkoss, D., ANd Luft, R.: Studies on sulfation factor (SF) activity of human serum. Serum SF in hypopituitarism and acromegaly. Acta Endocrinol., 36: 577 (1961).

2. Blodgett, F. M., Burgin, L., Iezzon, D., Gribetz, D., AND TALBOT, N. B.: Effects of prolonged cortisone therapy on the statural growth, skeletal maturation and metabolic status of children. New Engl. J. Med., 254: 636 (1956).

3. Cerilli, G. D., Nelson, E., and Dorfmann, L.: Renal transplantation in infants and children with the hemolytic-uremic syndrome. Surgery, 71: 66 (1972).

4. Collins, E. S., Anilane, J.: The response of costal cartilage to changes in hormonal environment. Experientia, 15: 116 (1959).

5. Daughaday, W. H.: Regulation of skeletal growth by sulfation factor. Advan. Intern. Med., 17: 237 (1971).

6. Daughaday, W. H., Hall, K., Raben, M. S., Salmon, W. D., JR., VAN Den Brande, J. L., and VAN WYK, J. J.: Somatomedin: Proposed designation for sulfation factor. Nature, 235 : 107 (1972).

7. Daughaday, W. A., and Kozak Mariz, J.: Conversion of proline $\mathrm{U}-\mathrm{C}^{14}$ to labelled hydroxyproline by rat cartilage in vitro: Effect of hypophysectomy, growth hormone and cortisol. J. Lab. Clin. Med., 59: 741 (1962).

8. Daughaday, W. H., and Parker, M. L.: Sulfation factor measurement as an aid in the recognition of pituitary dwarfism. J. Clin. Endocrinol. Metab., 23: 638 (1963).

9. Daughaday, W. H., Salmon, W. D., JR., and Alexander, F.: Sulfation factor activity of sera from patients with pituitary disorders. J. Clin. Endocrinol. Metab., 19: 743 (1959).

10. Fine, R. N., KoRsch, B. M., AND STILes, Q.: Renal homotransplantation in children. J. Pediat., 76: 347 (1970).

11. Glick, S., Roth, J., Yalow, R. S., and Berson, S. A.: Immunoassay of human growth hormone in plasma. Nature, 199: 784 (1963).

12. Gonzalez, L. L., Martin, L., West, C. D., Spitzer, R., and MCENERY, P.: Renal homotransplantation in children. Arch. Surg., 101: 232 (1970).

13. Greulich, W. W., ANd PyLe, S. I.: Atlas of Skeletal Development of the Hand and Wrist, Ed. 2 (Stanford University Press, Stanford, 1957).

14. HALL, K.: Human somatomedin. Acta Endocrinol., Suppl. I63 (1972).

15. Hall, K., Holmgren, A., and Lindahl, U.: Purification of a sulphation factor from skeletal muscle of rat. Biochim. Biophys. Acta, 201: 398 (1970). 
16. HALL, K., AND OLIN, P.: Sulphation factor activity and growth rate during long-term treatment of patients with pituitary dwarfism with human growth hormone. Acta Endocrinol., 69: 417 (1972).

17. Hawk, P., Oser, B., and Summerson, W.: Practical Physiological Chemistry, Ed. 13 (Blakiston Company, New York, 1954).

18. Kleeman, C. R., Taborsky, E., and Epstern, F. H.: Improved method for determination of inorganic sulfate in biologic fluids. Proc. Soc. Exp. Biol. Med., 91: 480 (1956).

19. Lilly, J. R., Glles, G., Hurwitz, R., Schroter, G., Takagr, H., Gray, S., Penn, I., Halgrimson, C., and Starzl, T. E.: Renal homotransplant in pediatric patients. Pediatrics, 47: 548 (1971).

20. McConaghey, P., AND Muller, J.: "Sulphation factor": Its production by the rat liver and kidney. Second International Symposium on Growth Hormone, May 5-7, 1971 (Excerpta Medica ICS Series No. 236, 26, 1971).

21. MCConaghey, P., And Sledge, C. B.: Production of "Sulphation Factor" by the perfused liver. Nature, 225: 249 (1970).

22. Moore, T. C., And Hume, D. M.: The period and nature of hazard in clinical renal transplantation. II. The hazard to transplant kidney function. Ann. Surg., 170: 12 (1969).

23. Morris, H. G., Jorgensen, J. R., Elrick, H., And Goldsmith, R. E.: Metabolic effects of human growth hormone in corticosteroid treated children. J. Clin. Invest., 47: 436 (1968).

24. Najarian, J. S., Simmons, R. L., Tallent, M. B., KJellstrand, C. M., Buselmeier, T., Vernier, R. L., and Michael, A. F.: Renal transplantation in infants and children. Ann. Surg., 174: 583 (1971).

25. National Academy of Sciences, National Research Council, Food and Nutrition Board: Recommended Dietary Allowances, Publication No. 1694, Ed. 7 (National Academy of Sciences, Washington, D.C., 1968).

26. New, M. I., Miller, B., And Peterson, R. E.: Aldosterone excretion in normal children and in children with adrenal hyperplasia. J. Clin. Invest., 45: 412 (1966).

27. Penny, R., Blizzard, R. M., and Davis, W. T.: Sequential arginine and insulin tolerance tests on the same day. J. Clin. Endocrinol. Metab., 29: 1499 (1969).

28. Potter, D., Belzer, F. O., Rames, L., Holliday, M. A., Kountz, S. L., ANd Najarian, J. S.: The treatment of chronic uremia in childhood. I. Transplantation. Pediatrics, 45: 432 (1970).

29. Roor, A. W., Bonglovanni, A. M., and Eberlein, W. R.: Studies of the secretion and metabolic effects of human growth hormone in children with glucocorticoid-induced growth retardation. J. Pediat., 75: 826 (1969).

30. Salmon, W. D., JR., and Daughaday, W. H.: A hormonally controlled serum factor which stimulates sulfate incorporation by cartilage in vitro. J. Lab. Clin. Med., 49: 825 (1957).

31. Samain, N. A., AND Freeman, R. M.: Growth hormone levels in severe renal failure. Metabolism, 19: 102 (1970).

32. Saxena, B. B., Demura, H., Gandy, H. M., and Peterson, R.
E.: Radioimmunoassay of human follicle stimulating and luteinizing hormones in plasma. J. Clin. Endocrinol. Metab., 28: 519 (1968).

33. Simmons, J. M., Wilson, C. J., Potter, D. E., and Holliday, M.: Relation of caloric deficiency to growth failure in children on hemodialysis and the growth response to calorie supplementation. New Engl. J. Med., 285: 653 (1971).

34. Soyka, L. F., ANd Crawford, J. D.: Antagonism by cortisone of the linear growth induced in hypopituitary patients and hypophysectomized rats by human growth hormone. J. Clin. Endocrinol. Metab., 25: 469 (1965).

35. Szigetr, M., Ezer, E., Szporny, L., and Fekete, G.: Acute inhibitory action of glucocorticoids on the uptake of sulfur by bone tissue in vivo. Steroids, 5: 729 (I965).

36. TAnner, J. M.: Growth at Adolescence, Ed. 2 (Blackwell Scientific Publications, Oxford, 1962).

37. Tanner, J. M., Whitehouse, R. H., and Taksishi, M. L.: Standards from birth to maturity for height, weight, height velocity and weight velocity: British children, 1965, Part II. Arch. Dis. Childhood, 41: 613 (1966).

38. West, C. D., And SMith, W. C.: An attempt to elucidate the cause of growth retardation in renal disease. Amer. J. Dis. Child., 91: 460 (1956).

39. Wiedemann, E., AND Schwartz, E.: Suppression of growth hormone-dependent sulfation factor by estrogen. J. Clin. Endocrinol. Metab., 34:51 (1972).

40. Wiedemann, E.: Unpublished results.

41. Williams, G. M., LeE, H. M., ANd Hume, D. M.: Renal transplants in children. Transplant Proc., 1: 262 (1969).

42. Wright, A. D., Lowy, C., Fraser, T. R., Spitz, I. M., Rubenstein, A. H., AND Bersohn, I.: Serum growth hormone and glucose intolerance in renal failure. Lancet, 2: 798 (1968).

43. We are grateful for the assistance of Vincent A. Panariello and John F. Saeli, biochemists, Metabolic Laboratory, Veterans Administration Hospital, Bronx, New York.

44. Dr. M. I. New is a recipient of the Career Scientist Award of the Health Research Council of The City of New York under contract U-2204.

45. Dr. S. Korth-Schutz was supported by the Deutsche Forschungsgemeinschaft.

46. This research was supported in part by Grant Awards HD 72, HL 12239, National Institutes of Health, United States Public Health Service, Grant Award RR 47 from the Division of General Medical Sciences, National Institutes of Health, United States Public Health Service; Grant CRBS-278, National Foundation-March of Dimes; The New York State Kidney Disease Institute and the Kidney Foundation of New York. Presented in part before the 43rd Annual Meeting of the Society for Pediatric Research, San Francisco, California, May 19, 1973.

47. Requests for reprints should be addressed to: P. SAENGEr, M.D., The New York Hospital-Cornell Medical Center, 525 East 68th St., New York, N. Y. 10021 (USA).

48. Accepted for publication October 10, 1973. 